\title{
GENERATIONAL DIVERSITY, PERSONAL ATTRIBUTES AND ORGANIZATIONAL COMMITMENT AMONG EMPLOYEES OF CORPORATE CONSULTANCIES
}

\author{
Purani Verasamy $^{1}$, Abdul Halim Abdul Majid ${ }^{2 *}$, Noor Asma Jamaluddin ${ }^{3}$ \\ ${ }^{1,2}$ School of Business Management, Universiti Utara Malaysia, 06010 UUM Sintok Kedah \\ ${ }^{3}$ School of Accountancy, Universiti Utara Malaysia, 06010 UUM Sintok Kedah \\ Email: ${ }^{1}$ vpurani88@gmail.com; ${ }^{2}$ ahalim@uum.edu.my; ${ }^{3}$ noorasma@uum.edu.my \\ *Corresponding author: ahalim@uum.edu.my
}

\begin{abstract}
The main objective of this paper was to examine relationships of generational diversity, personal attributes (i.e., work values; attitudes and behavior; and interpersonal skills) on organizational commitment among employees of corporate consultancies. The research framework contained four independent variables which were generational diversity, work values, attitude and behavior, and interpersonal skills. Meanwhile the dependent variable was organizational commitment (i.e., affective, continuance and normative). The survey was conducted among employees of 15 corporate consultancies in Kuala Lumpur. A total of 436 questionnaires were distributed and 241 questionnaires were returned which represented a response rate of $55.27 \%$. Statistical Package software for Social Science (SPSS) Version 24.0 was used to analyze the data. One-Way ANOVA and Pearson correlation coefficient were used to test the hypothesis. It was found that there was a significant difference among the three generations of workforce (i.e., baby boomers, generation X and generation $\mathrm{Y}$ ) on organizational commitment (affective, continuance and normative). Further, the Pearson correlation coefficient revealed that there were significant relationships between work values, attitude and behavior, and interpersonal skills of the three generations (baby boomers, generation $\mathrm{X}$ and generation $\mathrm{Y}$ ) towards organizational commitment (affective, continuance and normative).
\end{abstract}

Keywords: Commitment; work values; attitude and behavior; interpersonal skills; baby boomers.

\section{Introduction}

Most of the organizations in Malaysia consist of three different generations of workforce who are working together. For the purpose of this study, the generational diversity is referred to the Baby Boomers generation, Generation X, and Generation Y workforce. Each of these working groups has their own thought and opinion on organizational commitment. Similarly, each of the generation cohorts may have its own characteristic or personal attributes. In this present context, personal attributes are measured by work values, attitudes and behavior, and interpersonal skills. These attributes are beneficial when carrying out a specific task and can influence their organizational commitment. Meanwhile, the focus is very much related to the organizational commitment which also has three sub-dimensions that include affective, continuance and normative commitment. Thus, this paper highlighted the differences in the organizational commitment among three generations of employees by measuring their personal attributes such as work values, attitude and behavior, and interpersonal skills.

This preliminary research examined the relationship of generational diversity (Baby Boomers generation, Generation X, and Generation Y), and personal attributes (work values, attitudes and behavior, and interpersonal skills) towards organizational commitment (affective, continuance and normative commitment) among employees from corporate consulting firms in Kuala Lumpur. Specifically, the following were the research questions to be answered:

i. Is there any difference among the three generations of workforce on organizational commitment (affective, continuance and normative)?

ii. What is the relationship between work values and organizational commitment (affective, continuance and normative)?

iii. What is the relationship between attitude and behavior, and organizational commitment (affective, continuance and normative)?

iv. What is the relationship between interpersonal skills and organizational commitment (affective, continuance and normative)?

\section{Dependent Variable: Organizational Commitment}

The concept of organizational commitment was developed by Howard Becker in 1960's as the theory of commitment (Becker, 1960). Commitment is known as a force that drags a person into a course of action (Meyer, Stanley, Herscovitch, \& Topolnytsky, 
2001). Organizational commitment has been related with many important aspects in organizational research. This is because, organizational commitment has strong relationship with various working environment. For example, organizational commitment can be related with performance, productivity, turnover and many other loyalties related subjects in the organization.

Apart from few past studies on organizational commitment (Ahmad, Bibi, \& Abdul-Majid, 2017; AlMarri, Abdul-Majid, \& Bin-Abdullah, 2019; Ahmad, Abdul-Majid, \& Mohd-Zin, 2016; Allen \& Meyer, 1990) also contributed much earlier of crucial studies on organizational commitment. They stated that organizational commitment is the employee's relationship with the organization as a physiological attachment and this creates loyalty towards the organization. Affective, continuous, and normative commitment are the three components of organizational commitment which are generally used by researchers.

\section{Independent Variables: Generational Diversity and Personal Attributes}

In the context of this present paper, independent variables represent the inputs or causes, and were tested to see their influences on the dependent variable (organizational commitment). Other variables may also be observed for various reasons. However, the scope of this study covered only generational diversity (Baby Boomers generation, Generation X, and Generation Y workforce), and personal attributes (work values, attitude and behaviour, and interpersonal skills).

\section{Generational Diversity}

Generational diversity is a growing phenomenon in contemporary business environments, with distinct life experiences, values and skill sets working side by side. Companies must be prepared to manage conflicts arising from these differences, to capitalize on potential benefits of the conflicts and to reduce negative consequences. Table 1 identifies those three generations, and the following section briefly discusses each of those three generations.

\section{Table 1}

Working Generations, Birth Years and Age Ranges

\begin{tabular}{lll}
\hline Generations & Birth years & Age Ranges \\
\hline Baby Boomers & $1949-1964$ & 54 and above \\
Generation X & $1965-1980$ & $38-53$ \\
Generation Y & $1981-2001$ & $17-37$ \\
\hline
\end{tabular}

Sources: Zemke, Raines, and Filipczak, 2000
Baby Boomers were identified as people who reject the current cultural values. They were also acknowledged as people who are being slow (Connaway, 2007); yet they tend to think and speak with confidence; grow up before the social change starts; are very social and don't like loneliness. This character of Baby Boomers makes them being adapted to teamwork (Dann, 2007); also known as hardworking generation; high level of commitment (Connaway, 2007); may have many positive behaviour such as they are goal oriented and strive for their success, are loyal toward their organization and always working on top of their job requirements (Blythe et al., 2008; Broom, 2010).

Meanwhile, Generation X was classified as the generation born in the birth year 1965 to 1980 (Gursoy, Chi, \& Karadag, 2013; Park \& Gursoy, 2012); who had gone through economic recession (Park \& Gursoy, 2012); are open minded people (Gokul, Sridevi, \& Srinivasan, 2012); who seek freedom at the working environment (Park \& Gursoy, 2012); always have individualistic characteristics which may create disloyalty towards their organization (Gursoy, Maier, \& Chi, 2008; Park \& Gursoy, 2012). They always give more priority to their individual goal; do not believe that strong commitment is necessary to get rewards (Kupperschmidt, 2000); will not give full attention towards their organization; prefer to make their own decisions because of their personal individualistic character (Gursoy et al., 2013); give importance to work life balance; and tend to work in challenging and risk taking environment (Gursoy et al., 2013; Kupperschmidt, 2000; Gokul et al., 2012).

Generation Y was also identified as Millennials (Lajuni, Bujang, Karia \& Yacob, 2018), born in the year 1981 to 2001 (Zemke et al., 2000); shared same life experiences in social and environmental context (Gursoy et al., 2013; Park \& Gursoy, 2012); are said to be more creative, building social networks, have higher expectation in organization, high confidence level and technology savvy (Gursoy et al., 2013). They are also always expecting more social responsibilities and their own safety (Noble \& Schewe, 2003); not believing in empowerment, but they believe in themselves and their commitment towards the organization itself (Gokul et al., 2012).

\section{Personal Attributes}

The other independent variable in this study is labelled as personal attributes. Personal attributes in this present paper are measured by three sub-dimensions, namely work values, attitudes and behavior, and interpersonal skills. 
- Work Values - Value is known as the guideline or standard held by an individual, in personal and work life (Parry \& Erwin, 2011). Therefore, individual is inclined to decide or act according to his/her preferred work values.

- Attitude and Behavior - The employees' attitude towards their organization creates positive impact on the organization's development. Attitude is recognized as a powerful instrument that influences the behavior of an employee. Attitude of a person remains the same until some intervention or action are taken to change it. In the organization context, attitude and behavior of an employee play an important role to the success of organization. Thus, the managers can easily predict the behavior of an employee by looking into his/her attitude.

- Interpersonal Skills - Bambacas and Patrickson (2008) described that interpersonal skills comprise an individual's self-discovery, feelings and support; and as skills with communicational knowledge and self-development (Barrett, 2006). The skill is described as the ability of an individual to listen to others, how he/she passes messages and how he/she offers feedbacks.

\section{Conceptual Framework}

Figure 1 below displays the potential relationship between independent variables (generational diversity) and personal attributes (work values, attitude and behavior, and interpersonal skills) towards the dependent variable of organizational commitment (affective, continuance and normative commitment).

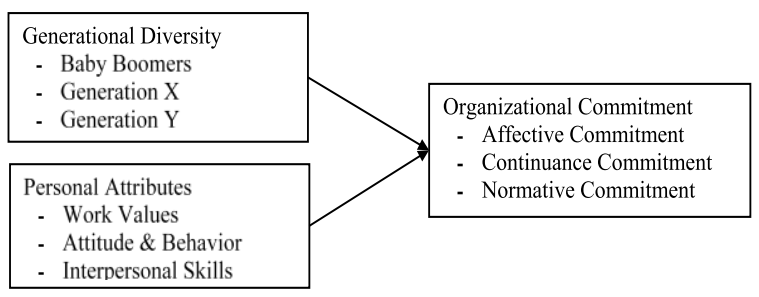

Figure 1. Conceptual framework

\section{Research Method}

The targeted population of this preliminary research was employees from 15 (fifteen) corporate consulting firm in Kuala Lumpur. By definition, a corporate consultant is a person who provides professional solution for corporate entities with his or her expertise. Basically corporate consultant serves in the area of management of specialized fields. Normally, corporate consultants have a wide knowledge of the subject matter because they are specialized in that area.
Corporate entities may refer to corporate consultancy firms to guide them to run their business.

In this research, the data was collected through the survey questionnaires. The questionnaire consists of three sections. Section A measures demographic profile of the respondents; section B assesses organizational commitment, and section $\mathrm{C}$ evaluates personal attributes. All the items in section B and C are measured using a 5-point Likert Scale. The Likert Scale used to measure the variables ranged from $1=$ strongly disagree to $5=$ strongly agree. All of these measures were basically adapted from the previous researchers as shown in Table 2.

\section{Table 2}

\section{Selection of Measures for Each Variable}

\begin{tabular}{lrll}
\hline \multicolumn{1}{c}{ Variables } & $\begin{array}{c}\text { No of } \\
\text { Items }\end{array}$ & Source of Scale Reliability \\
\hline $\begin{array}{l}\text { Organizational Commitment } \\
\text { 1. Affective Commitment }\end{array}$ & 8 & Allen and & 0.826 \\
2. Continuance Commitment & 8 & Meyer (1990) & 0.852 \\
3. Normative Commitment & 8 & & 0.865 \\
Personal Attributes & & & \\
1. Work Values & 4 & Mowday, & 0.920 \\
2. Attitudes and Behavior & 6 & Steers, and & 0.922 \\
3. Interpersonal Skills & 6 & Porter (1979) & 0.916 \\
& & & Long (2011) \\
\hline
\end{tabular}

In the context of this preliminary research, the total population was 436 employees representing of Baby boomers, Generation X and generation Y employees from 15 corporate consultancy firms in Kuala Lumpur. The details of corporate consultancies were derived from Companies Commission of Malaysia and the number of employees were confirmed through phone call.

A pilot test was also conducted to find out the reliability of the measures used for the dependent variable and independent variables. The result of the pilot study indicated that the data collected from the respondents are usable for continuing the study. The actual collected data then were tested using one-way ANOVA and Pearson correlation. The following section will discuss the data analysis and its findings.

\section{Result and Discussion}

The distribution of questionnaires was done properly without bias among the employees of the 15 corporate consultancies in Kuala Lumpur with 195 unreturned questionnaires as shown in Table 3. There were only 241 questionnaires out of the 436 distributed questionnaires were returned and usable, representing $55.27 \%$ response rate. 
Table 3

Response Rate and Percentage

\begin{tabular}{lc}
\hline \multicolumn{1}{c}{ Descriptions } & Frequency \\
\hline Number of distributed questionnaires & 436 \\
Returned questionnaires & 241 \\
Returned and usable questionnaires & 241 \\
Unreturned questionnaires & 195 \\
Response rate & $55.27 \%$ \\
\hline
\end{tabular}

From the data analysis, majority of the respondents are female consultants (60.2\%). Composition of the respondents include $74 \%$ of Generation $Y$ followed by $20 \%$ from Generation $\mathrm{X}$ and around $6 \%$ from Baby Boomers. Table 4 presents further information on respondent profile.

Table 4

Profile of Respondents

\begin{tabular}{llcc}
\hline & & $\begin{array}{c}\text { Frequency } \\
(n)\end{array}$ & $\begin{array}{c}\text { Percentage } \\
(\%)\end{array}$ \\
\hline Gender & Male & 96 & 39.8 \\
& Female & 145 & 60.2 \\
Age group by & $>$ 54 years old & 15 & 6.2 \\
Generation & 38-53 years old & 48 & 19.9 \\
& $17-37$ years old & 178 & 73.9 \\
Ethnicity & Malay & 104 & 43.2 \\
& Chinese & 14 & 5.8 \\
& Indian & 121 & 50.2 \\
No of years & Others & 2 & 0.8 \\
working & 0-5 years & 92 & 38.2 \\
& 6-10 years & 56 & 23.2 \\
& $11-15$ years & 40 & 16.6 \\
& 16-20 years & 22 & 9.1 \\
& 20 years or more & 31 & 12.9 \\
\hline
\end{tabular}

In addition, a simple descriptive analysis was performed to identify the mean scores and standard deviations for the dependent and independent variables. Based on 241 respondent's feedbacks, all were analysed and the findings of the descriptive analysis are shown in Table 5.

From Table 5, it presents the mean values and standard deviations for all variables for comparative purposes. Moreover, the standard deviations for the variables are between 0.04398 and 0.91356 . These imply the existence of acceptable variability in the data and yet are still within a tolerable variance.

\section{Finding 1: Research Question \#1 - Differences of Generational Diversity on Organizational Commitment (Affective, Continuance and Normative)}

One-way ANOVA analysis was applied to answer research question 1 (Sekaran \& Bougie, 2016). Given the generational diversity has been divided into three groups/cohorts which are Baby Boomers (54 years old and above), Generation X-ers (38-53 years old), and Generation Y-ers (17-37 years old); oneway ANOVA shows that there is statistically significant difference among the three dimensions of the organizational commitment.

The present research of the generational diversity was not equal, because most of the firms had a rather small number of baby boomer's employees. Due to these unequal sizes of generational group, thus a harmonic mean sample size was used when the Tukey HSD post hoc test was performed. This post hoc test was performed to evaluate the differences by pair between the means.

A one-way analysis of variance (ANOVA) was calculated on generational cohorts and organizational commitment level. For the affective commitment Baby Boomers generation shows $(M=4.37, S D=$ $0.23)$, Generation $\mathrm{X}(M=3.58, S D=0.61)$ and Generation Y shows $(M=3.38, S D=0.81)$. Affective commitment between Baby Boomers and Generation $\mathrm{X}$ is significantly difference. From a multiple comparison analysis (refer Appendix A), it is shown 0.78 mean decrease and the $95 \%$ confidence interval $(C I)$ is between 1.32-0.27, which is statistically significant at $p=0.001$. Other than that, affective commitment level between Baby Boomers and Generation $\mathrm{Y}$ is also significantly difference. Between Baby Boomers and Generation $\mathrm{Y}$, the mean decrease about 0.98 and the $95 \% C I(1.46-0.51)$, which statistically significant $(p$ $=0.000$ ). However, the affective commitment level of Generation $\mathrm{X}$ and Generation $\mathrm{Y}$ is not significantly different. From the result shown, the 0.2 mean decrease between Generation X and Generation Y, while the $95 \% C I$ is $0.48(-0.94)$, which is not significant $(p=$ $0.254)$.

Further, the post hoc Tukey HSD indicates a decrease in the continuance commitment level among Baby Boomers $(M=4.36, S D=0.04)$ and Generation X-ers $(M=3.42, S D=0.64)$, a mean decrease of 0.94 , $95 \% C I$ (1.45 to 0.42 ), which was significant ( $p=$ $0.000)$. Tukey indicates a decrease in the continuance commitment level for Baby Boomer $(M=4.36, S D=$ $0.04)$ to Generation $\mathrm{Y}(M=3.16, S D=0.79)$, a mean decrease of $1.2,95 \% C I$ (1.66 to 0.72$)$, which is statistically significant $(p=0.000)$. Tukey indicated a decrease in the continuance commitment level for Generation X $(M=3.42, S D=0.64)$ to Generation Y $(M$ $=3.16, S D=0.79)$, a mean decrease of $0.26,95 \% C I$ ( 0.54 to -0.03 , which is not statistically significant $(p=$ 0.086 ).

Similarly, the post hoc Tukey HSD indicates a decrease in the normative commitment level among Baby Boomers $(M=4.11, S D=0.80)$ and generation $\mathrm{X}(M=3.44, S D=0.57)$, a mean decrease of $0.67,95 \%$ $C I(1.15$ to 0.18$)$, which is significant $(p=0.004)$. 
Table 5

Descriptive Statistics of All Variables $(n=241)$

\begin{tabular}{|c|c|c|c|c|}
\hline Construct & Dimension & Generation & Mean & Standard Deviation \\
\hline \multirow[t]{9}{*}{ Independent Variables } & \multirow[t]{3}{*}{ Work Values } & $>54$ years old $(15)$ & 4.1500 & .26390 \\
\hline & & $38-53(48)$ & 3.8021 & .73107 \\
\hline & & $17-37(178)$ & 3.4424 & .91356 \\
\hline & \multirow[t]{3}{*}{ Attitude \& Behavior } & $>54$ years old $(15)$ & 4.0222 & .05864 \\
\hline & & $38-53(48)$ & 3.8333 & 68417 \\
\hline & & $17-37(178)$ & 3.3727 & .85261 \\
\hline & \multirow[t]{3}{*}{ Interpersonal Skills } & $>54$ years old $(15)$ & 3.9778 & .15258 \\
\hline & & $38-53(48)$ & 4.0486 & .50290 \\
\hline & & $17-37(178)$ & 4.0440 & .81386 \\
\hline \multirow[t]{9}{*}{ Dependent Variable } & \multirow[t]{3}{*}{ Affective Commitment } & $>54$ years old $(15)$ & 4.3750 & .23146 \\
\hline & & $38-53(48)$ & 3.5781 & .60726 \\
\hline & & $17-37(178)$ & 3.3848 & .80872 \\
\hline & \multirow[t]{3}{*}{ Continuance Commitment } & $>54$ years old $(15)$ & 4.3583 & .04398 \\
\hline & & $38-53(48)$ & 3.4219 & 64496 \\
\hline & & $17-37(178)$ & 3.1650 & .79284 \\
\hline & \multirow[t]{3}{*}{ Normative Commitment } & $>54$ years old (15) & 4.1083 & .07999 \\
\hline & & $38-53(48)$ & 3.4401 & .56551 \\
\hline & & $17-37(178)$ & 3.3511 & .75420 \\
\hline
\end{tabular}

Tukey indicates a decrease in the normative commitment level for Baby Boomer $(M=4.11, S D=0.80)$ to Generation Y $(M=3.35, S D=0.75)$, a mean decrease of $0.76,95 \% C I$ (1.19 to 0.31$)$, which is statistically significant $(p=0.000)$. Tukey indicates a decrease in the normative commitment level for Generation X $(M=3.44, S D=0.57)$ to Generation $\mathrm{Y}$ $(M=3.35, S D=0.75)$, a mean decrease of $0.09,95 \%$ $C I$ ( 0.35 to -0.18 , which was not statistically significant $(p=0.713)$.

In short, the findings showed that there was significant difference between Baby Boomers and Generation X, Baby Boomers and Generation Y in affective, normative and continuance commitment. Nevertheless, there is no significant difference between Generation X and Generation Y in organizational commitment (affective, continuance, normative). Therefore, the research question \#1 has been objectively answered.

\section{Finding 2: Research Question \#2 - Relationship between Work Values and Organizational Commitment (Affective, Continuance and Normative)}

For this purpose, the Pearson correlation analysis was executed to describe the strength of the connection between two or more variables quantitatively. The rules of thumb have been suggested to identify the strength of the relationship between all the variables (Hair, Celsi, Money, Samouel, \& Page, 2015).
Table 6 reveals the correlation coefficient value of work values for affective, continuance and normative commitment. Correlation coefficient value for affective commitment is 0.792 , while for continuance commitment is 0.515 , and for normative commitment is 0.662 . The correlation range for affective commitment falls between $0.71-0.90$ and is considered as high strength of correlation coefficients. So that the relationship between work values and affective commitment is not only significant but also shows a high correlation coefficient. Moreover, the positive value of correlation coefficient shows that the relationship between the two variables are interrelated. The $p$-value of the variable is 0.000 . Thus it can be concluded that there is a significant positive relationship between work values and affective commitment.

In spite of this, the correlation range for continuance and normative commitment falls between 0.410.70 . This is considered as moderate, so that the relationship between work value and continuance commitment; and between work values and normative commitment were moderate. But the positive value of correlation coefficient shows that the relationship between the two variables are interrelated. The $p$-value of the variables are 0.000 . Therefore, Table 6 has clearly revealed that there is significant positive relationship between work value and continuance commitment, as well as significant positive relationship between work value and normative commitment. Subsequently, it can also be concluded that there is significant positive relationship between work values and affective, normative and continuance commitment. 
Table 6

Pearson Correlations of Work Values and Organizational Commitment

\begin{tabular}{llccc}
\hline & & \multicolumn{2}{c}{ Organizational Commitment } \\
\hline & & $\begin{array}{c}\text { Affective } \\
\text { Commitment }\end{array}$ & $\begin{array}{c}\text { Continuance } \\
\text { Commitment }\end{array}$ & $\begin{array}{c}\text { Normative } \\
\text { Commitment }\end{array}$ \\
\hline \multirow{3}{*}{ Work Values } & Pearson Correlation & $.792^{* *}$ & $.515^{* *}$ & $.662^{* *}$ \\
& Sig. (2-tailed) & .000 & .000 & .000 \\
\hline$* *$ Correlation is significant at the 0.01 level (2-tailed) & & & 241 & 241 \\
\hline
\end{tabular}

**. Correlation is significant at the 0.01 level (2-tailed).

Table 7

Pearson Correlations of Attitude and Behavior, and Organizational Commitment

\begin{tabular}{llccc}
\hline & & \multicolumn{2}{c}{ Organizational Commitment } \\
\hline & & $\begin{array}{c}\text { Affective } \\
\text { Commitment }\end{array}$ & $\begin{array}{c}\text { Continuance } \\
\text { Commitment }\end{array}$ & $\begin{array}{c}\text { Normative } \\
\text { Commitment }\end{array}$ \\
\hline Attitude \& & Pearson Correlation & $.738^{* *}$ & $.456^{* *}$ & $.621^{* * *}$ \\
Behaviour & Sig. (2-tailed) & .000 & .000 & .000 \\
& $N$ & 241 & 241 & 241 \\
\hline
\end{tabular}

**. Correlation is significant at the 0.01 level (2-tailed).

Table 8

Pearson Correlations of Interpersonal Skills and Organizational Commitment

\begin{tabular}{llccc}
\hline & & \multicolumn{2}{c}{ Organizational Commitment } \\
\hline & & Affective Commitment & $\begin{array}{c}\text { Continuance } \\
\text { Commitment }\end{array}$ & $\begin{array}{c}\text { Normative } \\
\text { Commitment }\end{array}$ \\
\hline Interpersonal skills & Pearson Correlation & $.527^{* * *}$ & $.502^{* *}$ & $.554^{* * *}$ \\
& Sig. (2-tailed) & .000 & .000 & .000 \\
& $N$ & 241 & 241 & 241 \\
\hline
\end{tabular}

**. Correlation is significant at the 0.01 level (2-tailed).

\section{Finding 3: Research Question \#3 - Relationship Between Attitudes and Behavior, and Organizational Commitment (Affective, Continuance and Normative)}

In answering this research question, the Pearson correlation analysis is conducted, and the findings are presented in Table 7.

From Table 7, the correlation coefficient value of attitude and behavior is $r=0.738$ and $p=0.000$. This clearly shows that there is positive linear relationship between attitude and behavior, and affective commitment. Furthermore, the result also shows the correlation coefficient value of attitude and behavior, for continuance commitment is $r=0.456$ and $p=$ 0.000 . The range falls between $0.41-0.70$. It is considered as moderate strength of correlation coefficients. Although the relationship between attitude and behaviour, and continuance commitment is moderate; the positive value of correlation coefficient signifies that the relationship between the two variables are interrelated. Further, the $p$-value of the variable is 0.000 which suggests significantly related.
Besides that, Table 7 also reveals that there is a positive correlation between attitude and behaviour, and normative commitment $(r=0.621$ and $p=0.000)$. In view of that, it can be concluded that there are significant positive relationships between the attitude and behaviour, towards all the three (affective, continuance and normative) of organizational commitment.

\section{Finding 4: Research Question \#4 - Relationship Between Interpersonal Skills and Organizational Commitment (Affective, Continuance and Normative)}

Table 8 discloses the results from the Pearson correlation analysis related to research question 4 . The correlation coefficient value of interpersonal skills and affective commitment is $r=0.527$ and $p=0.000$. Table 8 shows that there was positive linear relationship between interpersonal skills and affective commitment. It also indicates that the correlation coefficient value of interpersonal skills for continuance commitment was $r$ $=0.502$ and $p=0.000$. The range falls between 0.41- 
0.70 and it is considered as moderate strength of correlation coefficients. Yet, the relationship between interpersonal skills and continuance commitment is still significant. Meanwhile, it also indicates that there is a positive correlation between interpersonal skills and normative commitment with $r$-value $=0.554$ and $p=0.000$. Considering these, evidently there are significant positive relationships between the interpersonal skills and affective, continuance and normative commitment.

\section{Conclusion and Implications}

The findings reported above support that there is a significant difference between generational diversity (Baby Boomers and Generation X as well as Baby Boomers with generation $\mathrm{Y}$ ) in terms of the three dimensions of organizational commitment. Apart from that, there are also significant relationships between work values, attitude and behaviour, and interpersonal skills of respective generational diversity on organizational commitment (normative, continuance and normative).

The first finding is basically consistent with Horvath's (2011) study which finds that different generations have different perceptions about career purpose and work ethics. The generational cohort theory is also supported, here. The theory describes employment design of different generational cohort of corporate consultancy employees are supposed to be based on mentality of each generation. Similarly, the second, the third and the fourth findings are also in accordance with previous literatures. These in other words, employees with high organizational commitment may have less tendency to leave or to change job. In contrast, job hoppers who are also known as people who keep changing jobs. For these job hoppers, loyalty and commitment towards their job and organizations is rather weak. Obviously, they would never stay long enough in the companies.

However, organizations may also have to improvise their strategies and perceptions on different cohorts (generational diversity). Finding innovative approaches to cater each and respective set of the cohort's characteristics could be of another challenge. Occasionally, there is always employee who is not satisfied and not committed and thus has intention to leave the organization. This is really a tough challenge to the organization that need to be addressed, strategically.

\section{References}

Ahmad, A., Abdul-Majid, A.-H., \& Mohd-Zin, M.-L. (2016). Coworker support as moderator on the relationship between hrm practices and organizational commitment: A proposed framework. Asian Journal of Multidisciplinary Studies, 4(4), 91-97.

Ahmad, A., Bibi, P., \& Abdul-Majid, A.-H. (2017). The impact of training \& development and transformational leadership over organizational commitment among academic staff in public tertiary institutions: The buffering role of coworker support. International Journal of Economic Perspectives, 11(1), 417-432.

Allen, N. J., \& Meyer, J. P. (1990). The measurement and antecedents of affective, continuance and normative commitment to the organization. Journal of Occupational Psychology, 63(1), 1-18. https://doi.org/10.11/j.20448325.1990.tb00506.x

Al-Marri, M. T. S., Abdul-Majid, A. H., \& Bin-Abdullah, H. H. (2019). Examining the effects of work values on employee commitment in UAE via literature survey. International Journal of Advances in Agriculture Sciences, 8(1), 60-69.

Bambacas M., \& Patrickson M. (2008). Interpersonal communication skills that enhance organisational commitment. Journal of Communication Management, 12(1), 51-72. https://doi.org/10.1108/ 13632540810854235

Barrett, D. J. (2006). Strong communication skills a must for today's leaders. Handbook of Business Strategy, 7(1), 385-390. https://doi.org/10.1108/ 10775730610619124

Becker, H. S. (1960). Notes on the concept of commitment. American Journal of Sociology, 66(1), 32-42. http://dx.doi.org/10.10 86/2 22820

Blythe, J., Baumann, A., Zeytinoglu, I. U., Denton, M., Akhtar-Danesh, N., Davies, S., Kolotylo, C. (2008). Nursing generations in the contemporary workplace. Public Personnel Management, 37(2), 137-159.

Broom, C. (2010). Entice, engage, endure: Adapting evidence-based retention strategies to a new generation of nurses. Journal of Healthcare Leadership, 2, 49-60.

Connaway, L. S. (2007). Mountains, valleys, and pathways: Serials users' needs and steps to meet them. Part I: Preliminary analysis of focus group and semi-structured interviews at colleges and universities. Serials Librarian 52(1/2): 223-36.

Dann, S. (2007). Branded generations: Baby Boomers moving into the senior's market. Journal of Product and Brand Management, 16(6), 429-431.

Gokul A., Sridevi G., \& Srinivasan, P. T. (2012). The relationship between perceived organizational support, work engagement and affective commitment. AMET International Journal of Management, July-Dec., 29-37. 
Gursoy, D., Chi, C. G.-Q., \& Karadag, E. (2013). Generational differences in work values and attitudes among frontline and service contact employees. International Journal of Hospitality Management, 32, 40-48. Https://doi.org/10.1016/ j.ijhm.2012.04.002

Gursoy, D., Maier, T. A., \& Chi, C. G. (2008). Generational differences: An examination of work values and generational gaps in the hospitality workforce. International Journal of Hospitality Management, 27(3), 448-458. http://doi.org/10. 1016/j.jhm.2007.1 1.002

Hair, F. J., Celsi M., Money, A. H., Samouel, P., \& Page, M. (2015). The essentials of business research methods. $3^{\text {rd }}$ edition. New York, NY: Routledge.

Horvath, M. R. (2011). Authority, age, and era: How to select jurors using generational theory. (Cover story). Verdict, 25(3), 1-22

Kupperschmidt, B. R. (2000). Multigenerational employees: Strategies for effective management. Health Care Manager, 19(1), 65-76.

Lajuni, N., Bujang, I., Karia, A. A., \& Yacob, Y. (2018). Religiosity, financial knowledge, and financial behavior influence on personal financial distress among millennial generation. Jurnal Manajemen dan Kewirausahaan, 20(2), 92-98. https://doi.org/10. 9744/jmk.20.2.92-98.

Long, L (2011). Be nice or pay the price: added value of interpersonal skills training on analogue consultation outcomes. Lindsey Taylor Long publication, 56.
Meyer, J. P., Stanley, D. J., Herscovitch, L. \& Topolnytsky, L. (2002). Affective, continuance, and normative commitment to the organization: A meta-analysis of antecedents, correlates, and consequences. Journal of Vocational Behaviour, 61(1), 20-52. https://doi.org/10.1006/jvbe. 2001.1842.

Mowday, R. T., Steers, R. M. \& Porter, L. W. (1979). The measurement of organizational commitment. Journal of Vocational Behaviour, 14(2), 224-247. https://doi.org/10.1016/0001-8791(79)90072-1.

Noble, S. M., \& Schewe, C. D. (2003). Cohort segmentation: An exploration of its validity. Journal of Business Research, 56(12), 979-987. https://psycnet.apa.org/doi/10.1016/S0148-2963(02)00268-0

Park, J., \& Gursoy, D. (2012). Generation effects on work engagement among U.S. hotel employees. International Journal of Hospitality Management, 31, 1195-1202. https://doi.org/10.1016/j. ijhm.2012.02.007.

Parry, E., \& Erwin, P. (2011). Generational differences in work values: A review of theory and evidence. International Journal of Management Review, 13(1), 79-96. https://doi.org/10.1111/j.1468-2370. 2010.00285.x

Sekaran, U., \& Bougie, R. (2016). Research method for business: A skill building approach. Singapore: John Wiley \& Sons Inc.

Zemke, R., Raines C. \& Filipczak, B. (2000). Generations at work: Managing the clash of veterans, boomers, xers and nexters in your workplace. $2^{\text {nd }}$ Ed. New York, NY: American Management Association.

Appendix A

Post Hoc Results for Generational Cohort and Organizational Commitment - Multiple Comparisons

\begin{tabular}{|c|c|c|c|c|c|c|c|}
\hline \multirow[b]{2}{*}{ Dependent Variable } & \multirow[b]{2}{*}{ Generation } & \multirow[b]{2}{*}{ Generation } & \multirow[b]{2}{*}{$\begin{array}{c}\text { Mean } \\
\text { Difference }\end{array}$} & \multirow[b]{2}{*}{ Std. Error } & \multirow[b]{2}{*}{ Sig. } & \multicolumn{2}{|c|}{$95 \%$ Confidence Interval } \\
\hline & & & & & & $\begin{array}{l}\text { Lower } \\
\text { Bound }\end{array}$ & $\begin{array}{l}\text { Upper } \\
\text { Bound }\end{array}$ \\
\hline \multirow{6}{*}{ Affective Commitment } & \multirow{2}{*}{$>54$ yrs old } & $38-53$ yrs old & $.79688^{*}$ & .22183 & .001 & .2737 & 1.3201 \\
\hline & & $17-37$ yrs old & $.99017^{*}$ & .20162 & .000 & .5146 & 1.4657 \\
\hline & \multirow{2}{*}{$38-53$ yrs old } & $>54$ yrs old & $-.79688^{*}$ & .22183 & .001 & -1.3201 & -.2737 \\
\hline & & $17-37$ yrs old & .19329 & .12197 & .254 & -.0944 & .4809 \\
\hline & \multirow{2}{*}{ 17-37 yrs old } & $>54$ yrs old & $-.99017^{*}$ & .20162 & .000 & -1.4657 & -.5146 \\
\hline & & $38-53$ yrs old & -.19329 & .12197 & .254 & -.4809 & .0944 \\
\hline \multirow{6}{*}{$\begin{array}{l}\text { Continuance } \\
\text { Commitment }\end{array}$} & \multirow{2}{*}{$>54$ yrs old } & $38-53$ yrs old & $.93646^{*}$ & .21932 & .000 & .4192 & 1.4537 \\
\hline & & $17-37$ yrs old & $1.19331^{*}$ & .19934 & .000 & .7232 & 1.6635 \\
\hline & \multirow{2}{*}{$38-53$ yrs old } & $>54$ yrs old & $-.93646^{*}$ & .21932 & .000 & -1.4537 & -.4192 \\
\hline & & $17-37$ yrs old & .25685 & .12059 & .086 & -.0276 & .5413 \\
\hline & \multirow{2}{*}{ 17-37 yrs old } & $>54$ yrs old & $-1.19331^{*}$ & .19934 & .000 & -1.6635 & -.7232 \\
\hline & & $38-53$ yrs old & -.25685 & .12059 & .086 & -.5413 & .0276 \\
\hline \multirow{6}{*}{$\begin{array}{l}\text { Normative } \\
\text { Commitment }\end{array}$} & \multirow{2}{*}{$>54$ yrs old } & $38-53$ yrs old & $.66823^{*}$ & .20633 & .004 & .1816 & 1.1549 \\
\hline & & $17-37$ yrs old & $.75721^{*}$ & .18754 & .000 & .3149 & 1.1995 \\
\hline & \multirow{2}{*}{$38-53$ yrs old } & $>54$ yrs old & $-.66823^{*}$ & .20633 & .004 & -1.1549 & -.1816 \\
\hline & & $17-37$ yrs old & .08898 & .11345 & .713 & -.1786 & .3565 \\
\hline & \multirow{2}{*}{ 17-37 yrs old } & $>54$ yrs old & $-.75721^{*}$ & .18754 & .000 & -1.1995 & -.3149 \\
\hline & & $38-53$ yrs old & -.08898 & .11345 & .713 & -.3565 & .1786 \\
\hline
\end{tabular}

*. The mean difference is significant at the 0.05 level 